\title{
YouTube Channel: An Alternative Social Media to Enhance EFL Students' Speaking Skill
}

\author{
Muhammad Ilyas ${ }^{1}$, Miranti Eka Putri ${ }^{2}$ \\ ${ }^{1}$ Universitas Islam Riau, Pekanbaru \\ email:m.ilyas@edu.uir.ac.id \\ ${ }^{2}$ Universitas Islam Riau, Pekanbaru \\ email: mirantiekaputri@edu.uir.ac.id
}

\begin{abstract}
The use of YouTube channel allows students to comprehend lessons easier and motivates students in learning. The aim of this study is to know whether or not there is a significant effect of using YouTube channel to students' speaking achievement. YouTube encourages positive learning attitude if it is incorporated in classroom teaching to supplement language learning especially speaking. The design of this study was experimental research that was conducted at English language study program of Universitas Islam Riau. 48 students of the first semester were selected as the sample of the study. After applying YouTube channel in teaching speaking, it was found that the value of sig. 2-tailed was 0.000 which is lower than the probability value of 0.05 . It means there was a significant improvement on students' speaking achievement after being taught by using YouTube channel.
\end{abstract}

Keywords: YouTube channel, Social Media, Teaching Speaking

\begin{abstract}
Abstrak
Penggunaan saluran YouTube memungkinkan siswa untuk memahami pelajaran dengan lebih mudah dan memotivasi siswa dalam belajar. Tujuan dari penelitian ini adalah untuk mengetahui apakah ada atau tidak pengaruh yang signifikan dari penggunaan saluran YouTube terhadap keterampilan berbicara siswa. YouTube dapat membuat siswa lebih mudah menerima pelajaran, memotivasi siswa dalam belajar, sehingga tujuan pendidikan dapat dicapai dengan baik. YouTube mendorong sikap belajar yang positif jika dimasukkan dalam pengajaran di kelas bahasa terutama keterampilan berbicara. Desain penelitian ini adalah penelitian eksperimental yang dilakukan di program studi pendidikan bahasa Inggris Universitas Islam Riau. Sampel penelitian ini terdiri dari 48 siswa semester pertama. Setelah mengaplikasikan saluran YouTube dalam pembelajaran, hasil penelitian menunjukkan peningkatan yang signifikan. Berdasarkan data SPSS, nilai sig. (2-tailed) adalah 0,000 yang tidak lebih besar dari nilai probabilitas yaitu $0,05(0,000<0,05)$. Hal ini berarti Ho ditolak dan $\mathrm{H} 1$ diterima, sehingga dapat disimpulkan bahwa terdapat pengaruh yang signifikan dari penggunaan saluran YouTube terhadap keterampilan berbicara siswa..
\end{abstract}

Kata Kunci: Saluran YouTube, Media Sosial, Pengajaran Keterampilan Berbicara 


\section{INTRODUCTION}

Oral communication often occurs in human life.In this case, the student of English education study program is expected to communicate orally in English (speaking). To master this speaking skill, students must learn how to engage speaking in English. Grauberg (1997: 201) reveals that many students who consider the primary purpose of learning a foreign language is to be able to speak the language. Therefore, Grauberg continued, the English lecturers should help the students to achieve the goals of the students by expelling all their best abilities.

English lecturers are expected to be able to improve students' motivation in learning better by creating an interesting situation that makes them actively ask, discuss, and express their ideas and feeling. The roles of lecturers are not only transferring information to the students but also facilitating the students to learn English. Motivation is the energy change in a person who is characterized by the emergence of feeling with a response to the goal.

Methods, techniques, approaches and media are the components of learning, objective and good material do not provide good results without selecting and using appropriate methods, techniques, approaches and media with the purposes and materials.

Students' four English language skills which are listening, speaking, reading, and writing with the base of large vocabulary and grammar. Speaking is one of important skills that should be mastered by English students especially those who are at English study program, Students are expected to be able to communicate well with other.

In this case, some students in English language study program of Universitas Islam Riau lack of interest and motivation in learning English. In learning a language skill, especially speaking, students usually find some difficulties when they are studying about grammar and vocabulary, and lack of confidence Teaching speaking is considered to become the most difficult lesson. The students need the mastery of pronunciation, structure, discourse, and the social context of cultural competence. Besides, speaking is difficult, more effort is required on the part of the students and teachers. It is not enough for the students to listen only. The speaking ability of students in English department of UIR is still low, although the English teaching has been emphasized on speaking ability.

They sometime do not have enough bravery to speak in front of the class and feel nervous when they speak up. To overcome those problems, teaching English especially teaching speaking can be integrated with media such as social media.Nowadays, social media is used to teach English in several levels. Students from elementary to university are very fond of social media, so this is expected to motivate them to learn. There are so many popular social media including facebook, intagram, youtube, whatsapp and manymore. Youtube is one of social media that can be integrated in teaching speaking, because utilizing YouTube channel in teaching is useful and beneficial for lecturers who are interested in technology for teaching purposes.

\section{Review of Literature}

Speaking ability is related to communicative competence. According to Brown (2000) a foreign language learning is viewed not only as a predictable development process but also as the creation of meaning through interactive negotiation among learners. It means that communicative competence is the aspect of our competence that enables us to convey and interpret the message and to negotiate 
meanings inter-personally within specific context.

Teaching speaking needs strategies and also roles; a lecturer must have a good role in order to help students to get more information from the materials.

There are four characteristics for a successful speaking activity according to Ur (1996) first, Learners talk as much as possible of a period of time allotted to the activity is occupied by learner talk. This may seem obvious but often most time is taken up with teacher talk or pauses. Second, class discussion is not dominated by a minority of talkative participants; all the group members get their chance to speak and contributions are fairly, evenly distributed. Third, learners are eager to speak because they are interested in the topic and have something new to say about it or because they want to contribute to achieve the task objectives. Last, learners express themselves in utterances that are relevant, easily comprehensible to each other, and of an acceptable level of language accuracy.

Speaking, especially in a foreign language, is a very demanding activity for all ages of learners. Speaking is expected to share understandings with other people using a foreign language. He needs to find the most appropriate words and also the correct grammar to convey meaning precisely and accurately. It is also very important to organize the discourse so that the interlocutor understands what the speaker says (Cameron, 2001).

Speaking ability is related to communicative competence. It means that communicative competence enables us to convey and interpret the message and to negotiate meanings inter-personally within specific context.

According to Brown (2000), there are four communicative competences: (1) Grammatical competence. Grammatical competence is an umbrella concept that includes increasing expertise in grammar (morphology, syntax), vocabulary, and mechanics which refers to basic sound of letters and syllables, pronunciation of words, intonation, and stress. (2) Discourse competence. It is ability we have to connect sentences in stretches of discourse and to form a meaningful whole out of a series of utterances. Discourse means everything from a simple spoken conversation to lengthy written text. (3) Sociolinguistic competence. It is the knowledge of the socio cultural rules of language and of discourse. Learners must have competence which involves knowing what is expected socially and culturally by users of the target language. (4) Strategic competence. It is the way learners achieve the goals. With reference of speaking, strategic competence refers to the ability to know when and how to take the floor, how to keep conversation going, and how to clear up communication breakdown as well as comprehension problems.

\section{Teaching Speaking}

Teaching speaking is more demanding on the teacher than the teaching of Any other language skills. The problems may come from learning the language itself, and also from the technical problems in teaching speaking (River, 1987). Moreover, River adds, such features as pitch, intonation, stress and duration, assimilation, juncture, elisions, liaisons at word boundaries and expensive features like tone of voice and gesture are often all but ignored. Those features are constrains dealing with the language. However, teachers may find more problems in teaching speaking which are related to the technical problems. They are student's interest and motivation, student's reluctance to involve themselves, grouping 
the students, teaching media, classroom management, assessment technique.

According to Harmer (2005), there are three suggestions if we are trying to get students to speak fluently: (1) Prompter. Students sometimes get lost, cannot thing of what to say next, or in some other ways lose the fluency. We can leave them or struggle out of such situation on their own, and indeed sometimes this may be the best option. However, we may be able to help them and the activity to progress by offering discrete suggestions. If this can be done supportively without disrupting the discussion, or forcing students out, it will stop sense of frustration that some students feel when they come to a dead end of language or ideas. (2) Participant. Teacher should be good animators while asking students to produce a language. Sometimes this can be achieved by setting up a clear activity and with enthusiasm. At other times, however, teachers may want to participate in discussion themselves. That way can prompt covertly, introduce new information to help the activity along, ensure continuing students engagement, and generally maintain a creative atmosphere. (3) Feedback provider. The vexed question of when and how to give feedback in speaking activities is by carefully considering the effects of possible different approach.

\section{Social Media}

Social media is the collective of online communications channels dedicated to community-based input, interaction, contentsharing and collaboration. Websites and applications dedicated to forum, microblogging, social networking, bookmarking, social curation, and wikis are among the different types of social media (Rouse, 2019).
Social media is an Internet based technology that is used to create and share online information, which helps facilitate knowledge and information sharing, collaboration, and participation (Evans, 2014). Furthermore, social media enables two or more peopleto interact and to communicate with each other. Social media platforms such as Google, Facebook, Twitter, LinkedIn, and YouTube hold a great potential of being an online channel to facilitate student learning by providing a vast opportunity for learners toaccess and gather information to build, modify, and share theirknowledge (Gaytan, 2013).

\section{YouTube Channel}

YouTube channel is a video sharing website in which users can upload, share and view videos. It is created in 2005, and it was founded by Chad, stevechen, and Jawal Karim, who were employees at PayPal Company. The domain name is www.youtube.com, and then it is developed as and grewrapidly as more than 100 million videos views per day. YouTube is classified as the third most visited website on the internet. In these days 2010, YouTube launched a new design to simplify its interface and increasing the time users spend on the site. It provides students with a visual connection to abstract literary theory, which help teachers to increase students' participation, and shed the light on context.

YouTube has been used in a variety of teacher-learning contexts (GarciaBarriocanal, Sicilia, Sanchez-Alonso, \& Lytras, 2011; Milliken, Gibson, O'Donnell, \& Singer, 2008; Redecker, et al., 2009). Apparently, teachers and students make use of it (Downes, 2008) as an educational resource: present a topic, develop activities in the classroom, produce videos, work with video resources, and also engage students in learning digital skills (Bonk, 2008; Burke \& 
Snyder, 2008; Snelson\& Perkins, 2009). It is also used for online classrooms and distance education courses to establish a sense of classroom community and achieve greater learner outcomes (Burke \& Snyder, 2008; Duffy, 2006). Besides, YouTube is considered an innovative way to learn for visually or physically impaired learners (Burke et al., 2009). YouTube videos can inspire and engage learners and support the digital learning style of the Net Generation (Burke \& Snyder, 2008).

\section{Integrating YouTube in Teaching Speaking}

YouTube is undeniably the most popular online video uploader that can be used for language learning. It can be incorporated in blended learning to substitute verbal input by the teacher to make the class more interactive (Ataei, 2012). The videos can be used in teaching speaking where the students are able to view the visual while listening to the speech. YouTube encourages positive learning attitude if it is incorporated in classroom teaching to supplement language learning especially speaking.

YouTube is a part of the advancement of information technology (IT) in thisglobalization era. YouTube is a website that shares various kinds of video like video clips, TV clips, music videos, movie trailers, and other content namely video blogging, short original videos, and educational videos (Jalaluddin, 2016).

The following arethe teaching procedure foryoutube video implementation in classroom as suggested by Cakir (2006).

a. Active viewing. It is necessary for students to take an active part on the video since this technique needs them to focus their attention on the main idea of the video. Before playing the video, the teacher should write some key questions on the board related to the video, so the students get an overview about the content of the video. The students may take a note during watching the video and after that they should answer the questions orally. For detail comprehension, the students can be given a cue sheet or viewing guide, then let them watch and listen for specific information needed.

b. Freeze Framing and Prediction. It means stopping the video at certain point so it shows certain picture on the screen by pressing pause button. After that the students are asked to predict about what action the character at the frozen picture on the screen will probably do, how is his/her feeling, and what will probably happen, or any other questions related to the picture. Freeze framing fires the imagination of the students by leading them to predict and deducing further information about the characters.

c. Silent viewing. It means that the video is playing with the sound off and is only using the moving picture. One way of doing this technique is the students are asked to observe the behavior of the character and use their deduction. Then pause the video at certain point to stop the moving picture on the screen and get students to guess what is happening and what the characters might be saying or ask students what has happened up to that point. After that, the video segment is replayed with the sound on, so that the students can compare their deduction with what actually happens in the video.

d. Sound on and vision off activity. This technique is used by removing the visual element of the video so that the students only can hear the dialogue but are unable to see the action. Then the students can be asked to guess the setting, action, characters, etc. from the soundtrack. 
e. Repetition and role-play. When there are some difficult language points in the video unit, a repetition can be a necessary way for communicative production exercises. Through this technique, the teacher replays difficult point of the video and asks the students to do repetition individually or in chorus. After the students have clear understanding about the difficult point they can be asked to act out the scene as much of the original version as they can remember before asking them to improvise the scene to fit their views of the situation and the characters they are playing.

Jigsaw viewing. To implement this technique, the teacher can instruct half of the students to go out of the classroom for few minutes and the rest are watching the video with sound off. Then the students switch places and the second group watch the video with the pictures off. Finally, they come back to share their ideas about what the video is about.

\section{METHOD}

The design of this research was quasi experimental research. It was intended to know whether or not there was a significant effect of using YouTube media on students' speaking skill. In this research there was one class as experimental class. Pre-test was administered before the treatment, post-test was administered after the treatment. There were two variables in this research, namely independent variable which was YouTube media in teaching and learning process and dependent variable which was speaking skill.

The researcher used random sampling method to determine the sample. The researcher chose one classfrom 2 classes which consists of 48 students from 101 students.
Seno (2014) explains that instrument is a tool that is used by writer to collect the data from sample, informant or object that being examined. Instrument can be classified based on it's form, type and variety, such as; social studies including language, literature and culture. The instrument was usually in the form of questions, questionaires and interviews. The instrument of this study was a speaking test. The test was administered to the sample twice in pre-test and post-test.

The following is the procedure of collecting data in pre-test (spoken test), treatment by using youtube media and posttest (spoken test).

\section{Adminstering pre-test}

The pre-test was given in the first meeting to know students' ability in speaking before treatment. The aim was to measure the basic ability of speaking before getting treatment by using youtube media.

2. Administering treatment

After giving pre-test, researcher gave treatment by using youtube media in teaching speaking in the class.

\section{Administering post-test}

The post-test was given at the end of meeting or after giving treatment. It conducted to know students' ability in speaking after treatment. The aim was to know the effect of using youtube media on students' speaking skill.

The scores obtained in pre-test and in post-test were analyzed by using paired sample t-test available in SPSS 22 to find the significant difference on the students' speaking achievement.

\section{FINDING AND DISCUSSION}

After collecting, the reseracher analysed these data. The following is the output of students' score in pre-test and post-test. 
Table 1.Compare Mean of Pre-Test and Post-Test

Paired Samples Statistics.

\begin{tabular}{|c|c|c|c|c|c|}
\hline & & Mean & $\mathrm{N}$ & $\begin{array}{c}\text { Std. } \\
\text { Deviation }\end{array}$ & $\begin{array}{l}\text { Std. Error } \\
\text { Mean }\end{array}$ \\
\hline \multirow{2}{*}{$\begin{array}{l}\text { Pai } \\
1\end{array}$} & Pre Test & 49,34 & 48 & 5,882 & ,849 \\
\hline & $\begin{array}{l}\text { Post } \\
\text { Test }\end{array}$ & 62,10 & 48 & 6,984 & 1,008 \\
\hline
\end{tabular}

Table 1 shows the mean scores in pretest and post-test. The mean score of pretest was 49.34 while the mean score of post-test was 62.10 and the difference was 12.76.

Table 3. Paired Sample.

Paired Samples Test.

\begin{tabular}{|c|c|c|c|c|c|c|c|c|c|}
\hline & & \multicolumn{5}{|c|}{ Paired Differences } & \multirow[t]{3}{*}{$\mathrm{t}$} & \multirow{3}{*}{$\mathrm{f}^{\mathrm{d}}$} & \multirow{3}{*}{$\begin{array}{l}\text { Sig. } \\
(2- \\
\text { tailed })\end{array}$} \\
\hline & & \multirow[t]{2}{*}{ Mean } & \multirow[t]{2}{*}{$\begin{array}{c}\text { Std. } \\
\text { Deviation }\end{array}$} & \multirow[t]{2}{*}{$\begin{array}{l}\text { Std. } \\
\text { Error } \\
\text { Mean }\end{array}$} & \multicolumn{2}{|c|}{$\begin{array}{l}95 \% \text { Confidence } \\
\text { Interval of the } \\
\text { Difference }\end{array}$} & & & \\
\hline & & & & & $\begin{array}{l}\text { Lowe } \\
\mathrm{r}\end{array}$ & Upper & & & \\
\hline $\begin{array}{l}\mathrm{Pa} \\
\text { ir } 1\end{array}$ & $\begin{array}{l}\text { Pre Test - } \\
\text { Post Test }\end{array}$ & $\begin{array}{r}- \\
12,767\end{array}$ & 4,374 & ,631 & $\begin{array}{r}- \\
14,037\end{array}$ & $\begin{array}{c}- \\
11,496\end{array}$ & $\begin{array}{r}- \\
20,220\end{array}$ & $7^{4}$ & 000 \\
\hline
\end{tabular}

Table 3 shows that the value of sig (2tailed) was 0.000 and the value of significant probability was 0.05 . So, the value of probability was higher than sig (2tailed) $(0.05>0.000)$. It means that the $\mathrm{Ha}$ was accepted and the $\mathrm{H} 0$ was rejected. In other words there was significance effect of using YouTube Channel on students' speaking achievement.

After collecting the score of pre-test and pos-test, the researcher analysed the improvement of students' score in pre-test and in post-test. 
Table 4. Increasing score from pre-test to post-test.

\begin{tabular}{|l|l|l|}
\hline Mean score of pre-test & Mean score of post-test & Improvement \\
\hline \hline 49.34 & 62.10 & $25.86 \%$ \\
\hline
\end{tabular}

Table 4 shows that the improvement was $25.86 \%$. It means that the score improvement was relatively high. Then, the data collected in pre-test and in post-test were analyzed to identify students' scores on each component in the speaking Table 5 shows the percentage of students' scores in each speaking component. assessment. It aims to find out which component which has the highest improvement after the use of YouTube channel. The components are vocabulary, grammar, pronunciation, fluency, and comprehension.

Table 5. Mean Score of Each Components.

\begin{tabular}{|c|c|c|c|}
\hline \multirow{2}{*}{ No } & $\begin{array}{l}\text { Indicators of } \\
\text { Speaking }\end{array}$ & $\begin{array}{c}\text { Mean Score } \\
\text { of Pre-test }\end{array}$ & Mean Score of Post-test \\
\hline 1 & Vocabulary & 49.27 & 60.13 \\
\hline 2 & Grammar & 49.41 & 61.69 \\
\hline 3 & Pronunciation & 49.31 & 65.02 \\
\hline 4 & Fluency & 49.46 & 61.73 \\
\hline 5 & Comprehension & 48.31 & 6 \\
\hline
\end{tabular}

The students' scores on each component in speaking improved from pre-test to posttest. The improvement of vocabulary was $22.04 \%$, grammar was $24.85 \%$, pronunciation was $24.98 \%$, fluency was $31.46 \%$, and comprehension was $27.78 \%$. From these results, it can be concluded that the fluency component experienced the greatest improvement. This is because in learning speaking by using YouTube channel requires students to repeat what they have heard. They can practice continuously and repeatedly after watching and comprehending the content of video. When there are some difficult language points in the video unit, a repetition can be a necessary way for communicative production exercises. Through this technique, the lecturer replays difficult point of the video and asks the students to do repetition individually.

Based on the calculation of the pre-test and post-test as stated before, it can be interpreted that there is improvement of students' speaking skill after treated by using YouTube channel in the class. Based on the data of SPSS, it can be seen that the value of sig. (2-tailed) was 0,000 which is not greater than the probability value of 0.05 . In other word it can be read $0.000<$ 0.05. Based on the score, the researcher concluded that Ho was rejected and $\mathrm{H} 1$ was 
accepted means that there is significant effect of YouTube channel towards students' speaking skill of first semester

\section{CONCLUSION}

Based on the research that have been done, the researcher found the students in the class that treated by using YouTube channel were more moativated. The researcher found the students were more care to participate in class and interacted with their classmates. They were confident to speak without worrying their limitation. Moreover, students were actively interacted with the lecturer and researcher during class. Furthermore, during the post-test, they were brave to speak in answering the question although they still had mistake but, it is less than in pre-test. It means the use of YouTube channel were effective to motivate students to be more active in the class.

Based on the data of SPSS, it can be seen that the value of sig. (2-tailed) was 0,000 which is not greater than the probability value of 0.05 . In other word it can be read $0.000<0.05$. Based on the score, the researcher concluded that Ho was rejected and $\mathrm{H} 1$ was accepted means that there is significant effect of YouTube channel towards students' speaking skill of first semester students at English language education of FKIP UIR.

\section{REFERENCES}

Ary, Donald. Lucy Cheser, and Asghar, R. 1979. Introduction to Research in Education. New York: Holt, Renehart and Winston.

Ataei, E. 2012. Using YouTube Videos to Teach Negotiation Skills in English Language Learning Master Dissertation. Malaysia: University Teknologi Malaysia. students at English language education of FKIP UIR.

Bonk, C. J. 2008. YouTube anchors and enders: The use of shared online video content as a macrocontext for learning.

Brown, H. Douglas. 2000. Principles of Language Learning and Teaching. (third edition). New Jersey: Prentice Hall.

Burke, S. C., \& Snyder, S. L. 2008. YouTube: An Innovative Learning Resource for College Health Education Courses. International Electronic Journal of Health Education, 11, 39-46.

Cakir, I. 2006. The Use of Audio-Visual Material in Foreign Language Teaching Classroom. The Turkish Online Journal of Educational Technology, 4(5), 67-72.

Cameron. 2001. Teaching Languages to Young Learners. Cambridge. Cambridge University Press.

Chastain, Kenneth. 1988. Developing Second Language Skills: Theory and Practice 3rd edition. San Dieago: Harcourt Brace Jovanovich.

Creswell, J. W. 2008.Educational Research: Planning, Conducting, and Evaluating Quantitative and Qualitative Research. New Jersey: Pearson Education.

Cryer, P. \& Elton, L. 1992.Active Learning in Large Classes and with Increasing Student Numbers 
(Sheffield: $\quad$ CVCP Staff Development Unit).

Cyril. J. 1988. Communicative Language Testing. New York: Prentice Hall.

Downes, S. 2008. Places to Go: YouTube. Innovate: Journal of Online Education, 4(5), 1-4. Retrieved from http://www.innovateonline.info/inde x.php?view $=$ article $\&$ id $=633$

Duffy, P. a. B., Axel. 2006. The Use of Blogs, Wikis and RSS in Education: A Conversation of Possibilities. Paper presented at the In Proceedings Online Learning and Teaching Conference Brisbane.

Evans, C. 2014. Twitter for teaching: Can social media be used to enhance the processof learning? British Journal of Educational Technology, 45, 902915.doi:10.1111/bjet.12099

Garcia-Barriocanal, E., Sicilia, M.-A., Sanchez-Alonso, S., \& Lytras, M. 2011. Semantic Annotation of Video Fragments as Learning Objects: A Case Study with "YouTube" Videos and the Gene Ontology. Interactive Learning Environments, 19(1), 25-44.

Gaytan, J. 2013. Integrating social media into the learning environment of theclassroom: Following social constructivism principles. Journal of Applied Research for Business Instruction, 11(1), 1.

Gibbs, J. 1997. Tribes: A New Way of Learning Together. Sausalito, CA: Center Source System.

Grauberg, Walter. 1997. The Elements of Foreign Language Teaching.
Clevedon: Multilingual Matters, Ltd.

Harmer, J. 2005. The Practice of English Language Teaching. England: Longman.

Jalaluddin, M. 2016. Using YouTube to Enhance Speaking Skills in ESL Classroom. English for Specific Purposes World, 17(50).

Kaplan Andreas M., Haenlein Michael. 2010. "Users of the world, unite! The challenges and opportunities of social media". Business Horizons53 (1).

61.doi:10.1016/j.bushor.2009.09.00 3.

Khalid Al-zyoud \& Muhammad Kabilan 2012. The Use of YouTube in Teaching English Literature The Case of Al-Majma'ah Community College, Al-Majma'ah University (Case Study). International Journal of Linguistics ISSN 1948-5425 2012, Vol. 4, No. 4.

McKeachie, W. J. 1994.Teaching tips: A guidebook for the beginning college teacher, $9^{\text {th }}$ ed. Lexington, MA: D, C. Heath.

Putra, Seno H. 2014. Cara-cara Penulisan Karya Ilmiah Populer dan Karya Ilmiah Akademik: Koran, Majalah, Makalah, Skripsi, Tesis dan Disertasi. Universitas Riau Press.

Riswandi, Diki. 2016. Use of YouTubeBased Videos to Improve Students' Speaking Skill. Proceeding The 2nd International Conference On Teacher Training and Education Sebelas Maret University Volume 2 Number 12016 ISSN: 25002 4124 
River, W. 1987. Interactive Language Teaching. Cambridge: Cambridge University Press.

Rouse, Margaret. 2019. How SAP is handling the social media explosion. Retrieved from https://whatis.techtarget.com/defini tion/social-media

Snelson, C., \& Perkins, R. A. 2009. From Silent Film to YouTube ${ }^{\mathrm{TM}}$ : Tracing the Historical Roots of Motion Picture Technologies in Education.

Suharsimi, Arikunto. 2010. Prosedur Penelitian: Suatu pendekatan praktik. Jakarta: Rineka Cipta.

Terantino, J. M. 2011. Emerging Technologies YouTube for foreign languages: You have to see this video. Language Learning \& Technology, 15(1), 10-16.

Thelen, H.A. 1960. Education and the Human Quest. New York: Harper and Row.

Thornbury, Scott. 1994. How to teach speaking. Longman, Kanisius: Kesainc Blanc.

Ur, Penny. 1996. A Course in Language Teaching Practice and Theory. Cambridge: Cambridge University Press. 